\title{
Wholesome nutrition: a suitable diet for the new nutrition science project
}

\author{
Claus Leitzmann* \\ Institute of Nutrition, Justus Liebig University, \\ Wilhelmstrasse 20, D-35392 Giessen, Germany
}

\begin{abstract}
Objective: To show that the practice of wholesome nutrition meets the demands of the concept of the new nutrition science, at present and in the future.

Method: To define 'wholesome nutrition', to describe its origin and to discuss its recommendations; and to cite practical examples showing that wholesome nutrition includes the dimensions and domains that are the basis of the concept of the new nutrition science.

Conclusion: The recommendations of wholesome nutrition are an effective implementation of the concept of the new nutrition science.
\end{abstract}

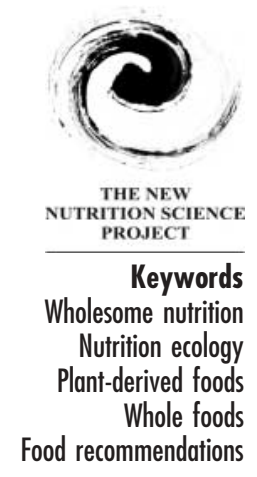

The concept of the new nutrition science is a necessary response to global developments, concerning among others health, population growth, resources and the environment. Most of the so-called advances during the last century have had serious consequences for the wellbeing of individuals, societies and the biosphere. To deal with these problems now is crucial and urgent.

A global view of nature with its interdependencies of living beings and physical entities was prominent in the understanding of the oldest human cultures on Earth and was maintained until the beginning of reductionism in science and industrialisation in agriculture. With this development, the global view was replaced by the division of science into various special disciplines that arose by need, interest and competence.

The conviction that a global view is needed to address the rising problems of health, environmental damages and decline of natural resources has become apparent only in recent decades. The negative influence of industrialised agriculture on the environment and its association with food quality have been the theme of influential books ${ }^{1,2}$. Curiously though, in modern societies there is not much mention of the nutritional wisdom accumulated in ancient human societies. Traditional indigenous populations have in many cases good nutritional rules, as shown by anthropological research ${ }^{3}$.

Linear thinking and standards based on quantity are now often challenged by synergistic ideas and qualitative values: for example, in Fritz Schumacher's concept that 'small is beautiful', and the work of Fritjof Capra'. This new way of thinking with its ancient roots has been applied to nutrition. Thus, the origins of what became known as 'nutrition ecology' are found in the start of the journal Ecology of Food and Nutrition in 1971, and in the work of Joan Gussow ${ }^{5}$.

Nutrition ecology takes a broad view of nutrition systems, and recommends what has become known as 'wholesome nutrition' as the most suitable and sustainable way to eat and drink ${ }^{6}$. This is in line with the new nutrition science project ${ }^{7}$, as it addresses all dimensions listed as important for this concept. Wholesome nutrition as defined (Box 1) is gaining increasing acceptance as a health-promoting, sustainable and equitable diet.

\section{Discussion}

\section{Historical aspects}

The health aspects of wholesome nutrition were formulated in ancient Greece by Hippocrates with his prophylactic medicine, and by Pythagoras who introduced the classical form of vegetarianism ("No food from dead animals'). They took a broad view of nutrition and ways of life. Similar developments took place at the same time in India and China. These ideas and experiences were later carried on by, among others, Paracelsus (1493-1541) and Hufeland (1762-1836).

The reform movement in Europe, beginning in the midnineteenth century, was a reaction to the negative effects of industrialisation on nature and man. Important pioneers of the present-day concept of wholesome nutrition were Max Bircher-Benner (1867-1939) ${ }^{8}$ with his clinical experiences and Werner Kollath $(1892-1970)^{9}$ with his experimental contributions. It was they who coined the term 'wholesome nutrition' and rediscovered the value of raw and minimally processed foods, that retain all essential and health-promoting substances necessary for supporting immune competence and self-healing 
The concept of the new nutrition science, based on sound scientific data, needs recommendations for its practical realisation. Wholesome nutrition fulfils this need, since it favours the consumption of mostly locally grown plant-based foods of highest quality. It is beneficial for health, ethically attractive and ecologically sustainable.

properties of the body. The concept of whole foods once more became important.

These pioneers were accompanied and followed by a number of physicians, dentists and nutritionists, who contributed to the further development of wholesome nutrition on the basis of their particular competence and experiences ${ }^{10-13}$.

The positive aspects of the advancement in agricultural production, industrial processing and preparation of foods and the progress in nutrition science, food chemistry, food analysis and food technology, needed to be integrated into wholesome nutrition. The concept of wholesome nutrition, therefore, combines new knowledge with the experiences tested by time resulting in recommendations that consider our evolutionary inheritance and meaningful research findings.

Wholesome nutrition as it is practised today mirrors the concept of the new nutrition science, in that it takes a broad view of nutrition by including biological, social, ecological and economic aspects of human concern. The two major principles are first the statement by Kollath': 'Leave our food as natural as possible', which consumers understand easily without scientific training or the need to consult experts or referring to books and tables. The second principle is the advice to eat predominantly food of plant origin. These are the basis for healthy and sustainable nutrition, now increasingly becoming the centrepiece of many national and international dietary guidelines, including various medical organisations in cardiology, gastroenterology, diabetology, oncology and orthopaedics.

The seven practical recommendations of wholesome nutrition, which implement the concept of the new nutrition science, are now elaborated.

\section{Enjoy your food}

Eating healthy foods is sensible and possible. However, the healthiest food does not help if it is not accepted, whatever the reason. One of the major obstacles to convincing people to eat healthy foods is their belief that health and enjoyment of food are incompatible. However, one positive experience convinces people that healthy foods can taste great. It is all a matter of selection, preparation and the way of serving.

In nutrition science, food quality usually is classified in three value categories: taste, health and use - in that

\section{Box 1 - The definition of 'wholesome nutrition'}

Wholesome nutrition consists mostly of foods of plant origin that have been processed as little as possible but as much as necessary. Fresh foods beneficial to health are prepared as tasty meals. The main foods to be eaten are vegetables, fruits, whole-grain products, legumes and nuts, as well as milk and dairy products. If desired, small amounts of meat, fish and eggs may be included. About half the amount of the food eaten consists of fresh raw foods (fruits, salads, nuts).

In addition to considering health, interactions of food and nutrition with the social, ecological and economic aspects are taken into account to achieve sustainability. This means among other things the preference of organic and seasonal food produced locally. The packaging of food should be environmentally benign. If foods from abroad are consumed, they should originate from fair trading. The concept of wholesome nutrition is encapsulated in seven recommendations ${ }^{1}$ :

1. Enjoy your food.

2. Choose foods of plant origin.

3. Select minimally processed foods.

4. Favour organic foods.

5. Prefer regional and seasonal foods.

6. Purchase environment-benign packaged foods.

7. Choose fairly traded foods.

\section{Reference}

1 Koerber Kv, Männle T, Leitzmann C. Vollwert-Ernährung: Konzeption einer zeitgemäßen und nachhaltigen Ernährungsweise, 10th ed. Stuttgart: Haug, 2004. 
order ${ }^{14}$. Tasty meals, served in a proper setting, increase enjoyment, positive thinking and well-being. All this has healthy effects on body and soul.

In addition to the three food quality values mentioned, additional categories of food quality are important. Wholesome nutrition is concerned with four aspects ${ }^{14}$ : these are individual (taste, health and usage); social (psychological, cultural and ethical); environmental (ecological); and economic (commercial).

\section{Choose foods of plant origin}

During human evolution over 50 million years, plantderived foods have been the major source of nutrition. Our anatomical and physiological characteristics have been modelled by these diets. A number of important food ingredients are found only in plants, like dietary fibres and phytochemicals; others are found primarily in plants, like unsaturated fatty acids and water. Even the much discussed fish oils are found in high concentration in certain plant products $^{15}$. Whereas the $n-3$ fatty acid content (mg per $100 \mathrm{~g}$ ) of tuna is equal to about 5000, mackerel 3000 and herring 2500, some plants can more than compete: for example, linseed with 16000 and walnut with 6000. Oils from plants have an even higher concentration: for example, linseed oil over 50000 , walnut and rapeseed oils about $10000 \mathrm{mg}$ per $100 \mathrm{~g}$.

In comparison, foods of animal origin contain, in addition to valuable nutrients, also saturated fats, cholesterol and a higher concentration of purines. Processed meat products often contain added salt, phosphates and other substances to improve the physical appearance and taste of these products.

A vast array of foods of plant origin are nutrient-dense (Box 2); this is especially important for physically inactive, affluent populations, who have low energy needs compared with physically active populations.

In recent years a lively discussion concerns the question of whether concentrations of nutrients in plant foods have been declining. Thorough analyses show that there are no tendencies for either decreasing or increasing nutrient concentrations during the last 50 years ${ }^{16}$. This is not surprising, since plants require, except for selenium, iodine and chromium, the same minerals for growth and development as man. The plant can synthesise all vitamins

\section{Box 2 - Nutrient and energy density}

The health value of a particular food depends not only on its absolute and proportional content of essential nutrients, but also on the relationship of essential and energy-containing nutrients. For this relationship the term 'nutrient density' has been coined, usually measured as amount per $1000 \mathrm{kcal}$. By this criterion the most valuable foods are vegetables, especially in raw form. The least valuable foods are among others isolated sugar (only energy), chips (French fries) and highly refined flours, and a great range of fatty, sugary, salty and highly processed products.

The concept of nutrient and energy density is especially helpful for physically inactive or obese individuals. Their nutrient need remains the same as in physically active and slim people, but their energy intake should be reduced. Therefore, nutrient-dense foods that are low in energy are the proper choice.

The following table lists the average nutrient density of some food groups ${ }^{1}$.

\begin{tabular}{|c|c|c|c|c|c|c|}
\hline & \multicolumn{2}{|c|}{ Vegetables } & \multirow[b]{2}{*}{ Fruits raw } & \multirow{2}{*}{$\begin{array}{l}\text { Wholemeal } \\
\text { flour cooked }\end{array}$} & \multirow{2}{*}{$\begin{array}{l}\text { Meat } \\
\text { cooked }\end{array}$} & \multirow{2}{*}{$\begin{array}{c}\text { Milk } \\
\text { pasteurised }\end{array}$} \\
\hline & Raw & $\overline{\text { Cooked }}$ & & & & \\
\hline \multicolumn{7}{|l|}{ Vitamins (mg per $1000 \mathrm{kcal})$} \\
\hline Vitamin A & 7.3 & 6.1 & 0.4 & 0.04 & 1.1 & 0.5 \\
\hline Vitamin $\mathrm{B}_{1}$ & 2.9 & 2.2 & 0.9 & 1.2 & 1.3 & 0.5 \\
\hline Vitamin $B_{2}$ & 2.7 & 2.3 & 0.9 & 0.4 & 0.7 & 2.9 \\
\hline Folic acid & 2.1 & 0.3 & 0.2 & 0.1 & 0.01 & 0.1 \\
\hline Vitamin C & 1200 & 1100 & 505 & - & - & 15 \\
\hline \multicolumn{7}{|l|}{ Minerals (mg per $1000 \mathrm{kcal})$} \\
\hline Magnesium & 810 & 530 & 250 & 370 & 110 & 190 \\
\hline Potassium & 13160 & 8050 & 3800 & 830 & 1760 & 2450 \\
\hline Calcium & 1940 & 1250 & 370 & 120 & 31 & 1875 \\
\hline Iron & 45 & 23 & 11 & 10 & 9 & 2 \\
\hline Zinc & 14 & 13 & 2 & 9 & 11 & 7 \\
\hline Dietary fibre (g per $1000 \mathrm{kcal})$ & 106 & 83 & 43 & 19 & - & - \\
\hline
\end{tabular}

\section{Reference}

1 Koerber Kv, Männle T, Leitzmann C. Vollwert-Ernährung: Konzeption einer zeitgemässen und nachbaltigen Ernährungsweise, 10th ed. Stuttgart: Haug, 2004. 
needed for its metabolism. The mineral and vitamin concentrations in foods of plant origin are determined by different internal (genetics, ripeness) and external (soil, climate and fertilisers, among others) factors. The genetic make-up of a plant can be responsible for three- or four-fold differences in the vitamin $\mathrm{C}$ content in different apples $(6-27 \mathrm{mg} \text { per } 100 \mathrm{~g})^{16}$.

A wide range of concentrations of different nutrients is also observed for many other foods of plant origin, with differences of up to 13 -fold. The concentrations of minerals and vitamins in fruits can either increase or decrease by up to $50 \%$ during development. A 12 -fold increase in the concentration of $\beta$-carotene in green pepper has been observed in the final phase of growth ${ }^{16}$.

In addition to the different factors discussed, there are other influences on the data in tables of nutrients like the chemical form of the vitamins listed, whether the food is analysed as fresh or dry weight, and the analytical methods employed, which have improved dramatically during the last decades. For these reasons it is problematical to compare data from older tables with more recent publications.

Traditionally fermented foods played a major role in the nutrition security of humankind. Fermented foods are mainly of plant origin, and have played a crucial role in human nutrition for millennia. In addition to their excellent storage properties, they are considered as health-promoting, due to their contents of vitamins, organic acids and live bacteria population ${ }^{17}$. Porridges made from germinated cereals and fermented flours are very favourable in the feeding of young children for five reasons. First, they do not thicken as much as plain porridges. Second, they can be prepared with less water to contain more energy and nutrients in a smaller volume. Third, iron is better absorbed. Fourth, they are easier to digest. Fifth, they contain fewer pathogens.

In addition to the health aspects, the predominant consumption of plant foods helps to solve some

\section{Box 3 - Advantages of vegetarian diets}

Wholesome vegetarian diets offer distinct advantages compared with diets based on meat and other foods of animal origin. The benefits include lower intakes of saturated fat, cholesterol and animal protein, as well as higher intakes of complex carbohydrates, dietary fibre, magnesium, folic acid, vitamins $\mathrm{C}$ and $\mathrm{E}$, carotenoids and other phytochemicals ${ }^{1}$.

Since vegetarians consume widely divergent diets, a differentiation between various types of vegetarian diets is necessary. Many contradictions and misunderstandings concerning vegetarianism are due to scientific data from studies without this differentiation ${ }^{2}$.

In the past, vegetarian diets have been described as being deficient in several nutrients including protein, iron, zinc, calcium, vitamins $\mathrm{B}_{12}$ and $\mathrm{A}, n-3$ fatty acids and iodine. Numerous studies have demonstrated that the observed deficiencies are usually due to poor meal planning. Vegetarian diets are beneficial in the prevention and treatment of certain diseases, such as cardiovascular disease, hypertension, diabetes, some types of cancer, osteoporosis, renal disease and dementia, as well as diverticular disease, gallstones and rheumatic arthritis. The reasons for choosing a vegetarian diet often go beyond health and well-being and include among others economical, ecological and social concerns. The influences of these aspects of vegetarian diets contribute to sustainable lifestyles and human development ${ }^{3-5}$.

The advantages of vegetarian ways of life have been recognised by a number of professional organisations, leading to position statements for example by the American Dietetic Association and the Dietitians of Canada ${ }^{1}$ :

1. Appropriately planned vegetarian diets are healthful, nutritionally adequate, and provide health benefits in the prevention of certain diseases.

2. Well-planned vegan or other types of vegetarian diets are appropriate of all stages of the life cycle, including during pregnancy, lactation, infancy, childhood and adolescence.

3. Vegetarian diets offer a number of nutritional benefits, including lower levels of saturated fat, cholesterol and animal protein, as well as higher levels of carbohydrates, dietary fibre, magnesium, potassium, folate and antioxidants such as vitamins C, E and phytochemicals.

\section{References}

1 American Dietetic Association (ADA) and Dietitians of Canada (DOC). Position of the ADA and DOC: vegetarian diets. Journal of the American Dietetic Association 2003; 103: 748-65.

2 Leitzmann C. Vegetarian diets: what are the advantages? In: Elmadfa I, ed. Diet Diversification and Health Promotion [special issue]. Forum Nutrition 2005; 57: 147-56.

3 Leitzmann C. Nutrition ecology: the contribution of vegetarian diets. American Journal of Clinical Nutrition 2003; 78: $657 \mathrm{~S}-9 \mathrm{~S}$

4 Leitzmann C, Hahn A. Vegetarismus. Stuttgart: Ulmer, 1996.

5 Sabaté J, ed. Vegetarian Nutrition. Boca Raton, FL: CRC Press, 2001. 
ecological problems caused by the industrial production of animal-derived foods, especially the need for large areas of acreage for feed production. Countries like India, where plant-derived foods are dominant in the diet, feeds more than $16 \%$ of the world's population with less than $8 \%$ of the world's arable land at its disposal.

Also, the emission of carbon dioxide and methane as well as nitrate pollution of water and foods are side-effects of factory animal production (see recommendation 4).

Furthermore, there are distinct social advantages of eating food predominantly of plant origin. The problem of world-wide malnutrition could be significantly reduced if traditional foods eaten in some parts of the world were not exported to be used as feeds in industrialised animal production. It requires economic incentives and therefore political action to enable local populations to buy the foods produced in their own countries. Some advantages of vegetarian diets are summarised in Box 3.

\section{Select minimally processed foods}

Raw food has been the sole source of nutrition throughout the largest part of our evolution and its consumption has been recommended since antiquity. In the last two centuries, more and more of our food has been processed and now makes up to $95 \%$ of the food consumed. Food processing has merits since it makes certain foods palatable and can destroy toxic substances. However, methods such as cooking destroy heat-labile substances like vitamins and phytochemicals. Other food processing methods such as milling eliminate vitamins, minerals and dietary fibres. One example of nutrient loss by food processing is the production of white flour (Table 1).

Another example of the dramatic loss of valuable food ingredients is the production of apple juice. The average concentration of the anticarcinogenic substance quercetin in apples is $150 \mathrm{mg}$ per $100 \mathrm{~g}$, whereas in apple juice it is only $5 \mathrm{mg}$ per $100 \mathrm{ml}$, a loss of $97 \%$. A further example is the

Table 1 The vitamin and mineral contents of wheat flour: whole and white ${ }^{14,18}$

\begin{tabular}{lccc}
\hline & $\begin{array}{c}\text { Wholemeal } \\
\text { flour }\end{array}$ & White flour & Loss (\%) \\
\hline Vitamins $(\mu$ g per 100 g) & & & \\
Vitamin E & 1400 & 300 & 78 \\
Vitamin $B_{1}$ & 460 & 60 & 87 \\
Vitamin $B_{2}$ & 94 & 30 & 68 \\
Vitamin $B_{6}$ & 270 & 180 & 33 \\
Nicotinic acid & 5100 & 700 & 86 \\
Pantothenic acid & 1200 & 210 & 82 \\
Folate & 87 & 10 & 88 \\
Biotin & 6.0 & 1.5 & 75 \\
Minerals (mg per $100 \mathrm{~g})$ & & & \\
Potassium & 381 & 108 & 72 \\
Calcium & 39 & 15 & 54 \\
Magnesium & 97 & 6 & 94 \\
Iron & 3.2 & 1.5 & 53 \\
Zinc & 2.6 & 0.7 & 73 \\
Dietary fibre (g per $100 \mathrm{~g})$ & & & \\
Cellulose & 13.5 & 4 & 70 \\
\hline
\end{tabular}

production of potato chips, where the end product is not only poorer in essential nutrients, but also richer in undesirable ingredients such as fats, salt, preservatives and other additives (Table 2). This applies equally to French fries.

Minimally processed foods are environmentally benign, since they require very little fossil energy prior to consumption. Therefore, carbon dioxide and sulfur dioxide emissions are smaller. For the consumer it is beneficial that fresh foods often cost less than processed foods, which have to be pasteurised/sterilised and packaged. Social aspects of purchasing fresh foods at food markets or the farm are that consumers stay more in contact with the producers of foods. The preparation of meals using whole foods is a social event when cooking and eating together.

\section{Favour organic foods}

Current applications of industrialised agricultural practices can lead to massive problems for soil, water and air and for the ecological system in its entirety. Some of the problems caused by intensive agriculture are nitrate pollution of soil, water and forests; phosphorus oversupply in soil and water; pesticide contamination of soil and water; loss of biodiversity; erosion and compaction of soil; high usage of fossil energy and resources; high contribution to the greenhouse effect; and contamination of food and drinking water with residues of pesticides, veterinary drugs and nitrate.

Organic farming has become well established within the European Union (EU) and is expanding at a steady rate. The leading countries with above $10 \%$ of their agricultural areas in organic farms are Austria and Switzerland, followed by the Scandinavian countries. The United Kingdom and Germany are around 4\% (the average value for the EU), below $1 \%$ are Greece and Ireland. Data on other countries are scanty; however, there are sizeable areas of organic farming in Australia, New Zealand and the USA.

The principles of organic farming add up to a holistic view of the food production system as an interaction of soil, micro-organisms, plants, animals and man. Principles of organic farming are the preservation and enhancement of soil fertility; raising plants and animals of the region; rotation of crops; production of healthy plants and animals; limitation on the number of livestock; ample running space for animals; minimal usage of fossil energy; and preservation and care of the cultivated landscape.

Table 2 Changes in nutrient concentrations in the production of potato chips $^{14,18}$

\begin{tabular}{lccc}
\hline Component & $\begin{array}{c}\text { Boiled } \\
\text { potatoes }\end{array}$ & $\begin{array}{c}\text { Potato } \\
\text { chips }\end{array}$ & $\begin{array}{c}\text { Change } \\
(\%)\end{array}$ \\
\hline Energy (kcal per $100 \mathrm{~g})$ & 70 & 540 & +770 \\
Fat (g per $100 \mathrm{~g})$ & 0.1 & 14 & +1400 \\
Minerals (\%) & 100 & 60 & -40 \\
Vitamin C (mg per 100 g) & 14 & 8 & -57 \\
Salt & Trace & Much & $\uparrow$ \\
Price & Low & High & $\uparrow$
\end{tabular}


In addition to these principles it is not allowed to use a number of problematical production aids employed in conventional agriculture, such as chemical-synthetic pesticides; mineral nitrogen fertilisers; chemical-synthetic growth regulators; veterinary drugs as feed supplements; and genetically engineered organisms.

With these measures, the greatest possible protection of the environment and of food quality are achieved. Organic farming is directed towards sustainability and is the farm system of the future.

\section{Prefer regional and seasonal foods}

A large proportion of the foods we eat is imported from other regions or countries, completely independent of the prevailing season. The transport of these foods over long distances and around the world is costly and requires an expensive infrastructure and large amounts of fossil energy. The shipping of food is driven less by real need, but by trade interests. It does not serve food and nutrition security in high-income countries, but harms it in low-income countries. Bananas and oranges (usually shipped by boat) have to be imported, but does it have to be green beans from Africa, strawberries from South America and asparagus from Asia, often transported by plane? The answer is that there should be a selection and preference of regional and seasonal foods. The emission of greenhouse gases by the transport of foods is huge and the additional noise, vibrations, accidents, traffic jams and compaction of soil could be substantially reduced by preferring regional foods.

Seasonal foods have the advantage that they are harvested close to the optimal ripening stage. This allows the plant to produce all the phytochemicals making up part of the health value of vegetables and fruits, such as colours and aromatic substances.

\section{Purchase environment-benign packaged foods}

Foods are packaged for various reasons, some of the most important being ease of transport and longer shelf-life, protection against spoilage, and giving products a desired shape. Liquid foods have to be packed or canned, they could hardly be commercialised without containers. However, the rubbish in our households largely derives from package material for foods. Although in some countries like Germany household rubbish is sorted into metals, glass, paper and organic material for recycling, the use of resources and the environmental impact are immense. Many foods such as potatoes, fruits, legumes and nuts could be sold unpackaged; others could be wrapped in plain paper without glossy pictures and advertisements. The amount of metals, paper and plastic used in present-day distribution systems could be reduced substantially by considering environmental concerns.

\section{Choose fairly traded foods}

With the globalisation of the food industry and the present powers of influence, small and medium-sized farms are at a disadvantage in the production, processing and trade of their products. Subsidies and duties favour big companies in highly industrialised countries. The subsidy system for food production in Europe is a remnant of the time of food scarcity after World War II. Commercial interests have kept it alive and make it the biggest expense in the budget of the EU, at over $€ 30$ billion per year. This outdated policy is also found in other countries outside Europe. It has led to an overproduction of certain foods like grains, vegetables, sugar, milk and wine, exactly the products that are most heavily subsidised. Grains, oil seeds and milk are subsidised with close to $€ 30$ billion, the surplus amounts to 33 million tons. Beef is subsidised with only $€ 1.6$ billion with a surplus of only 0.2 million tons ${ }^{14}$.

The losers in this protective policy are the people in low-income countries. To remedy this situation, the concept of 'fair trade' has been initiated with the possibility for consumers to support small-scale producers in low-income countries by buying fairly traded products. The international organisation of fair trade has defined and set goals (Box 4). The term 'fair' has social and ethical as well as economic connotations. Fair trade is an instrument of development aid and a step to more equity. This goal

\section{Box 4 - Definition and goals of 'fair trade'}

Fair trade is an alternative to conventional commercial trade. It is a partnership aspiring to a sustainable development for struggling and disadvantaged producers. This is accomplished by better conditions of trade, by improving awareness and campaigns.

The goals of fair trade are:

1. Improvement of the income situation and wellbeing of producers by an increased access to the market, strengthening the producer organisations, better payment for products and allowing a continuous trade relationship.

2. Support of the development potential for disadvantaged producers, especially women and indigenous populations, as well as protection of children from exploitation in the work process.

3. Strengthening the awareness of consumers about the negative consequences of international trade for the producers, to use their purchasing power in a supporting way.

4. Exemplifying partnership in trade employing dialogue, transparency and respect.

5. Implementation of campaigns to change the rules and practice of conventional international trade.

6. Protection of human rights by supporting social equity, environmental-benign behaviour and economic security. 
Table 3 Recommendations of wholesome nutrition for food consumption ${ }^{14}$

\begin{tabular}{llll}
\hline \multicolumn{4}{c}{ How much and how often to consume } \\
\hline Generously & Moderately & Seldom & Avoid \\
\hline Vegetables & Nuts & Canned foods & Isolated sugars \\
Fruits & Oil seeds & White flour products & Sweets \\
Wholemeal products & Native oils & Refined fats & Isolated substances \\
Potatoes & Butter & Meat products & Ready-to-eat \\
Legumes & Milk (products) & Alcohol & highly \\
Spices & Meat, fish, eggs & & processed \\
Water & Salt & & products \\
& Honey & \\
\hline
\end{tabular}

can be achieved by supporting fair trade on all levels of Western societies from governments to the individual.

\section{General considerations}

The concept of the new nutrition science is an invitation to consider not only individual health but also that of society, the environment and the planet as a whole, as citizens and consumers and also as health professionals. Wholesome nutrition already responds to this invitation, as do the traditional food systems in Mediterranean and Asian countries. The main recommendations of wholesome nutrition are to favour plant-derived whole foods, processed as little as possible but as much as necessary. The concept encompasses social and environmental as well as the biological precepts of the new nutrition science. In terms of foods, its recommendations are simple and can be followed by consumers around the world (Table 3 ).

Wholesome nutrition contributes to local and global food and nutrition security. It is convincing in taste, valuable for health, ecologically imperative, socially acceptable, culturally desired, economically plausible, scientifically well founded and practically feasible. It is the practical implementation of the concept of the new nutrition science.

But changing from any typical industrialised diet to wholesome nutrition demands conviction, insight and endurance. Changes to any established diet are never easy. With wholesome nutrition the taste of the meals may be somewhat different, the digestion system has to get used to the dietary fibre-rich foods, and foods from organic farming may be more expensive.

\section{Conclusion}

The concept of the new nutrition science, based on sound scientific data, includes recommendations for its practical realisation. Some aspects of the new nutrition science have been implemented as long as there has been human consciousness. Other aspects are found in some of the present-day diets valued for their taste, health-promoting effects and sustainability. The key elements of a suitable diet consider all dimensions of the new nutrition science. Consumers have to be motivated to retain all valuable elements of their traditional local food patterns and to add only those elements that have independently proved to be helpful for health, sustainability and equity.

Wholesome nutrition together with a sensible way of life translates the concept of the new nutrition science into real life. This diet can be adapted to almost any location on Earth, if the traditional, cultural, ethnic and environmental variables of a given society are respected. It is the alternative to what are now typical industrialised diets, because wholesome nutrition is beneficial for health, ethically attractive and ecologically sustainable.

\section{References}

1 Carson R. Silent Spring. Greenwich, CT: Fawsett, 1962.

2 Meadows D. The Limits of Growth. New York: University Books, 1978.

3 Jones T. With Bitter Herbs They Shall Eat It. Chemical Ecology and the Origins of Human Diets and Medicine. Tuscon, AZ: University of Arizona Press, 1990.

4 Capra F. The Turning Point. New York: Bantam Books, 1982.

5 Gussow J. The Feeding Web. Palo Alto, CA: Bull Publishing, 1978.

6 Spitzmueller E-M, Schoenfelder-Pflug K, Leitzmann C. Ernährungsökologie: Essen zwischen Genuss und Verantwortung. Heidelberg: Haug, 1993.

7 The Giessen Declaration. Public Health Nutrition 2005; 8(6A): $783-6$.

8 Bircher-Benner M. Grundzüge der Ernährungstherapie. Berlin: Salle, 1903.

9 Kollath W. Die Ordnung unserer Nabrung. Stuttgart: Hippokrates, 1942.

10 Bruker MO. Unsere Nabrung - unser Schicksal. Lahnstein: emu, 1969.

11 Loeckle WE. Bewusste Ernährung und gesunde Lebensführung. Schaffhausen: Novalis, 1978.

12 Schnitzer JG. Der alternative Weg zur Gesundheit. München: Mosaik, 1982.

13 Anemueller H. Naturheilverfahren - Ernährungstherapie. Stuttgart: Hippokrates, 1980.

14 Koerber K, Männle T, Leitzmann C. Vollwert-Ernährung: Konzeption einer zeitgemässen und nachbaltigen Ernährungsweise, 10th ed. Stuttgart: Haug, 2004.

15 DACH (German, Austrian and Swiss Nutrition Societies). Reference Values for Nutrient Intake. Frankfurt: Braus Umschau, 2002.

16 DGE (German Society of Nutrition). Ernäbrungsbericht. Bonn: DGE, 2004.

17 Campbell-Platt G. Fermented Foods of the World. Cambridge: Woodhead Publishing, 2000.

18 Souci SW, Fachmann W, Kraut H. Die Zusammensetzung der Lebensmittel-Nährwert-Tabellen. Stuttgart: Medpharm, 2000. 